\title{
Evaluation of Natural Regrowth of Axonopus aureus under rest periods in Roraima's
}

\section{Savannas}

\author{
Avaliação da rebrota natural de Axonopus aureus sob períodos de descanso nos cerrados de \\ Roraima
}

Evaluación del rebrote natural de Axonopus aureus bajo períodos de descanso en las sabanas de Roraima

Newton de Lucena Costa ORCID: https://orcid.org/0000-0002-6853-3271 Empresa Brasileira de Pesquisa Agropecuária, Brazil E-mail: newton.lucena-costa@embrapa.br

Antônio Neri Azevedo Rodrigues

ORCID: https://orcid.org/0000-0002-1231-4352 Instituto Federal de Educação, Ciência e Tecnologia de Rondônia, Brazil E-mail: azevedorodrigues9@gmail.br

\begin{abstract}
The natural regrowth of Axonopus aureus in native pasture of Roraima's savannas was evaluate, during early rainy period. The experimental design was a completely randomized, with four replications. The treatments consisted of four pasture rest periods $(14,28,42$ and 56 days after beginning of the rainy period). Evaluations were carry out during the period of June to August of 2016. The parameters measured were dry matter (DM) yields and grass morphogenetic and structural characteristics. The green and total DM, number of tillers plant ${ }^{-1}$, number of axillary tillers plant ${ }^{-1}$, number of live tillers plant ${ }^{-1}$, number of live leaves tiller ${ }^{-1}$ and leaf area index were directly proportional to rest periods. The leaf appearance and elongation rate were negatively affect by rest periods, while the dead DM was not affect by rest periods. Considering the low green DM availability of A. aureus, its recommends the utilization of some management practice, preferentially grazing or mowing, to remove the dead DM with low nutrition value and permit a grass vigorous regrowth in the beginning of the rainy period.
\end{abstract}

Keyword: Dry matter; Leaves; Morphogenesis.

\section{Resumo}

Avaliou-se a rebrota natural de Axonopus aureus em pastagens nativas dos cerrados de Roraima, no início do período chuvoso. Os tratamentos consistiram de quatro períodos de descanso (14, 28, 42 e 56 dias decorridos o início do período chuvoso). O delineamento experimental foi inteiramente casualizado com quatro repetições. As avaliações foram realizadas no período de junho a agosto de 2016. Os parâmetros mensurados foram rendimento de forragem e características morfogênicas e estruturais da gramínea. Os rendimentos de matéria seca verde e total, número total de perfilhos planta ${ }^{-1}$, número de perfilhos axilares, número de perfilhos vivos e índice de área foliar foram diretamente proporcionais aos períodos de descanso, ocorrendo o inverso quanto à taxa de aparecimento e de expansão de folhas, enquanto que os rendimentos de matéria seca morta não foram afetados. Considerando-se a baixa disponibilidade de matéria seca verde de A. aureus, recomenda-se a utilização de alguma prática de manejo, preferencialmente o pastejo ou a roçagem, de modo a remover o material morto e de baixo valor nutritivo e permitir uma rebrota mais vigorosa da gramínea no início do período chuvoso.

Palavras-chave: Matéria seca; Folhas; Morfogênese.

\section{Resumen}

Se evaluó el rebrote natural de Axonopus aureus en pastizales nativos en las sabanas de Roraima, al comienzo de la temporada de lluvias. Los tratamientos consistieron en períodos de descanso (14, 28, 42 y 56 días después del comienzo de la temporada de lluvias). El diseño experimental fue completamente al azar con cuatro repeticiones. Las evaluaciones se realizaron de junio a agosto de 2016. Los parámetros medidos fueron el rendimiento de forraje y las características morfogénicas y estructurales de la gramínea. Los rendimientos de materia seca verde y total, número total de macollas planta ${ }^{-1}$, número de macollas axilares, número de macollas vivas e índice de área foliar fueron directamente proporcionales a los períodos de descanso, ocurriendo lo opuesto en cuanto a las tasas de aparición y expansión de las hojas, mientras que los rendimientos de materia seca muerta no se vieron afectados. Considerando la baja disponibilidad de materia seca verde de A. aureus, se recomienda utilizar alguna práctica de manejo, 
preferiblemente pastoreo o siega, con el fin de remover material muerto y de bajo valor nutricional y permitir más rebrote al comienzo de la temporada de lluvias.

Palabras clave: Materia seca; Hojas; Morfogénesis.

\section{Introduction}

The native pastures of the farms of Roraima, despite quantitative and qualitative limitations, have historically provided food support for livestock exploitation, which has become, over the years, the main economic activity in the region (Costa et al., 2008). The continuous grazing system with variable stocking rate, but in general extensive to over extensive and disconnected from the seasonal productive rhythm, has a direct contribution to the low productive indexes of the herds. As a way to improve feeding conditions, breeders use fire, a practice of pasture management aimed at eliminating uneaten and hardened forage, providing an improvement in nutritional value when in early stages of growth, where the grass becomes more tender (Braga, 1998). In the native pastures of the farms, where the grass Axonopus aureus represents between 30 and $45 \%$ of its botanical composition, the animal production can be very low, which makes the livestock activity economically unfeasible in areas where there is its predominance, provided that practices are not implemented for its improvement (Gianluppi et al., 2001).

Over the years, fire has been the only management element and the great selector of native grass species in this ecosystem, being use up to three times a year, constituting an important ecological factor in the region, but with highly reflexes significant and negative effects on environmental liabilities arising from livestock activities (Braga, 1998; Costa et al., 2008). Studies carried out with different types of native pastures in tropical regions demonstrated the harmful effects of fire on the physical and chemical characteristics of the soil, in addition to providing ephemeral and low magnitude increases in forage yield and quality. Despite being relatively stable ecosystems, native pastures, managed under fire, do not allow the obtaining of technical and environmental indicators that ensure their economic sustainability, which implies an obsolete livestock exploitation with few prospects for evolution (Costa et al., 2013). Therefore, the adoption of alternative practices to burning emerge as management tools that can substantially modify and improve the traditional systems of livestock exploitation in the region. Thus, the knowledge of morphogenetic and structural characteristics provides a visualization of the seasonal forage production curve and an estimate of its quality (Pereira, 2013), in addition to allowing the proposition of distinct management practices specific to each forage grass (Lemaire et al., 2011; Tesk et al., 2020).

In this work were evaluate forage yield and structural and morphogenic characteristics of natural regrowth of Axonopus aureus pastures at different rest periods, in the beginning of the rainy season.

\section{Methodology}

The research was a field research trial, and perform under environment natural conditions and use the quantitative method. As there are still gaps about the effect of the rest periods defoliation regimes on the productive performance of native tropical forage pastures, it was choose to use the hypothetical-deductive method (Pereira et al., 2018).

The trial was conducted at the Embrapa Roraima Experimental Field, located in Boa Vista (60 $43^{\prime} 51^{\prime \prime}$ west longitude and $2^{\circ} 45^{\prime} 25^{\prime \prime}$ north latitude), from June to August 2016, which corresponded to an accumulated precipitation of 1,416 mm and an average monthly temperature of $24.79^{\circ} \mathrm{C}$. The climate of the region, according to Köppen's classification is Awi, characterized by well-defined dry and rainy periods of approximately six months each. Annual rainfall is 1,600 mm, with $80 \%$ occurring in the period from April to September. The soil of the experimental area is a Yellow Latosol, medium texture, with the following chemical characteristics, at a depth of $0-20 \mathrm{~cm}: \mathrm{pH}_{\mathrm{H} 2 \mathrm{O}}=4,8 ; \mathrm{Ca}=0.25 \mathrm{cmol}_{\mathrm{c}} \cdot \mathrm{dm}^{-3} ; \mathrm{Mg}=0.65 \mathrm{cmol}_{\mathrm{c}} \cdot \mathrm{dm}^{-3} ; \mathrm{K}=$ 
$0.01 \mathrm{cmol}_{\mathrm{c}} \cdot \mathrm{dm}^{-3} ; \mathrm{Al}=0.61 \mathrm{cmol}_{\mathrm{c}} \mathrm{dm}^{-3} ; \mathrm{H}+\mathrm{Al}=2.64 \mathrm{cmol}_{\mathrm{c}} \cdot \mathrm{dm}^{-3} ; \mathrm{SB}=0.91 \mathrm{cmol}_{\mathrm{c}} \cdot \mathrm{dm}^{-3} ;$ Cation Exchange Capacity $=3.6$ $\mathrm{cmol}_{\mathrm{c} .} \cdot \mathrm{dm}^{-3} ; \mathrm{V}(\%)=25.6$ and $\mathrm{m}(\%)=40$.

The experimental design was complete randomized with four replications. The treatments consisting of four rest periods (14, 28, 42 and 56 days after the beginning of the rainy season). Each experimental unit was represent by a plot with $2.0 \mathrm{~m}^{2}$, with a useful area of $1.0 \mathrm{~m}^{2}$. The evaluations were carried out in a pasture that was not subjected to physical (burning), mechanical (mowing) or biological (grazing) methods for lowering at the end of the dry period.

The parameters evaluated were dead dry matter yield (DDM), green dry matter (GDM), total dry matter (TDM), plant tiller number (PTN), axillary tillers number (ATN), live tillers number (LTN), live leaf tiller $^{-1}$ number (LLN), leaf area index (LAI), leaf appearance rate (LAR) and leaf expansion rate (LER). With the exception of DM yields that were determined throughout the useful area of the plot, for the other variables, the evaluations were carry out in four tussock plot $^{-1}$, selected according to their heights and diameters, in order to represent the variability of the population of plants in each plot. LAR, LER and LAI were determined only in live tillers. LAR and LER were calculate by dividing the accumulated leaf length and the total number of leaves in the tiller, respectively, by the regrowth period.

To calculate the leaf area, samples of completely expanded green leaves were collect, trying to obtain an area between 200 and $300 \mathrm{~cm}^{2}$. The samples were digitalize and the leaf area estimated with the aid of an electronic optical Planimeter ( $\mathrm{Li}-$ Cor 3100C). Subsequently, the sample was take, to the greenhouse with forced air at $65^{\circ} \mathrm{C}$ until they reached constant weight, obtaining the leaf GDM. Specific leaf area (SLA) was determine by the relationship between green leaf area and its GDM $\left(\mathrm{m}^{2} / \mathrm{g}\right.$ leaf GDM). The LAI was determined from the product of the total green leaf GDM $\left(\mathrm{g} \mathrm{GDM} / \mathrm{m}^{2}\right)$ by SLA $\left(\mathrm{m}^{2} / \mathrm{g}\right.$ leaf GDM).

The data were subject to analysis of variance and regression considering the significance level of 5\% probability. In order to estimate the response of the parameters evaluated to the rest periods, the choice of regression models was reason on the significance of the linear and quadratic coefficients, using the Student's " $t$ "test, at the level of $5 \%$ probability.

\section{Results and Discussion}

The DGM yields were not affected $(\mathrm{P}>0.05)$ by rest periods, with average forage availability of $2,341 \mathrm{~kg} / \mathrm{ha}$. The GDM and TDM were positively and linearly increase with larger rest period (Table 1). These values are lower than those reported by Heringer and Jacques (2002) for native pastures in Rio Grande do Sul managed in the absence of fire or clearing $(3,025 \mathrm{~kg} / \mathrm{ha})$. However, in both situations, the availability of forage, despite being satisfactory in quantitative terms, is characterize by low nutritional value as consequence of the high proportion of senescent leaves and would hardly be consumed by the animals, given its high levels of fiber and low concentration of nutrients. Most native grasses in the Roraima's savannas have high retention of senescent leaves, which can negatively affect nutrient recycling processes, making it necessary to use some management practice, preferably grazing or mowing, in order to favor a fast and vigorous regrowth, consisting of forage with high nutritional value and great acceptability by the animals. 
Table 1. Dead dry matter (DDM), green dry matter (GDM), total dry matter (TDM), plant tiller number, plant axillary tiller number, live tiller number and live leaf number of Axonopus aureus, as affected by rest periods.

\begin{tabular}{cccccl}
\hline \multirow{2}{*}{ Variables } & \multicolumn{3}{c}{ Rest Periods (days) } & \multirow{2}{*}{ Regression Equation } \\
\cline { 2 - 5 } & 14 & 28 & 42 & 56 & \\
\hline DDM $\left(\mathrm{kg} \mathrm{ha}^{-1}\right)$ & 1,875 & 2,345 & 2,521 & 2,623 & $\mathrm{Y}=2,037+30.551 \mathrm{X}\left(\mathrm{r}^{2}=0.94\right)$ \\
GDM $\left(\mathrm{kg} \mathrm{ha}^{-1}\right)$ & 458 & 724 & 857 & 1,039 & $\mathrm{Y}=1,736+17.214 \mathrm{X}\left(\mathrm{r}^{2}=0.89\right)$ \\
TDM $\left(\mathrm{kg} \mathrm{ha}^{-1}\right)$ & 2,333 & 3,069 & 3,378 & 3,662 & $\mathrm{Y}=301.9+13.336 \mathrm{X}\left(\mathrm{r}^{2}=0.92\right)$ \\
Plant Tiller Number & 11.2 & 19.7 & 20.2 & 18.5 & $\mathrm{Y}=0.95+1.0707 \mathrm{X}-0.0132 \mathrm{X}^{2}\left(\mathrm{R}^{2}=0.92\right)$ \\
Plant Axillary Tiller Number & 4.1 & 6.8 & 7.3 & 7.9 & $\mathrm{Y}=3.55+0.085 \mathrm{X}\left(\mathrm{r}^{2}=0.90\right)$ \\
Live Tiller Number & 4.3 & 6.7 & 9.2 & 8.8 & $\mathrm{Y}=0.71+0.3864 \mathrm{X}-0.0038 \mathrm{X}^{2}\left(\mathrm{R}^{2}=0.89\right)$ \\
Live Leaf Number & 2.2 & 4.9 & 5.8 & 5.1 & $\mathrm{Y}=2.15+0.3721 \mathrm{X}-0.0043 \mathrm{X}^{2}\left(\mathrm{R}^{2}=0.93\right)$ \\
\hline
\end{tabular}

Source: Research data.

Senescence is the natural process that characterizes the last phase of leaf development. It's start after its complete expansion and progressively accentuated with the increase in leaf area, due to the shading of the leaves inserted in the lower portion and the low supply of photosynthetically active radiation, in addition to strong competition for light, nutrients and water between the different strata of the plant (Nabinger \& Pontes, 2002). When tiller reach a certain number of live leaves, there is a balance between the rate and appearance and the senescence of leaves that have exceed their life span. So that the appearance of a new leaf implies in the senescence of the leaf that preceded it, so that the number of live leaves is relatively constant (Lemaire et al., 2011).

Despite the negative effect on forage quality, senescence represents an important physiological process in grass tissue flow, as about $50 \%$ of the carbon and $80 \%$ of the nitrogen can be recycled from senescent leaves and used by the plant for the production of new leaf tissues (Carrèrre et al., 1997; Lemaire \& Agnusdei, 2000; Tesk et al., 2020). Senescence negatively affects forage quality, however it represents an important physiological process in grass tissue flow, as around 35; 68; 86 and $42 \%$ of nitrogen, phosphorus, potassium and magnesium, respectively, can be recycled from senescent leaves and used to produce new leaf tissue (Sarmiento et al., 2006; Costa et al., 2013).

Considering an available use efficiency forage of $50 \%$ and an average daily intake of $11.25 \mathrm{~kg}^{\circ} \mathrm{GDM}^{\mathrm{AU}}{ }^{-1}(\mathrm{AU}=$ $450 \mathrm{~kg}$ of live weight), which represents $2.5 \%$ of the animal's live weight (Costa, 2014; Costa et al., 2021). So the availability of GDM record in this work would provide grazing periods of 20.2; 32.1; 38.1 and 46.2 days, respectively for rest periods of 14, 28, 42 and 56 days. Thus, as long as no pasture management practices are adopt, it is recommend start grazing 56 days after the beginning of the rainy season. Mochiutti et al. (2009), evaluating forage availability from native pastures in the Amapá's savannas, submitted to annual, biennial or clearing burning, estimated yields of 1,$302 ; 1,493$ and 1,353 kg/ha of TDM, respectively, which were lower than those obtained in this work.

The plant tiller number (PTN), live tillers number (LTN) and the live leaf number (LLN) were fitted to the quadratic regression model, with the maximum values estimated at 41.1; 50.8 and 43.2 days, while the axillary tillers number (ATN) was directly proportional to the rest periods (Table 1). The correlation between LTN and GDM yield was positive and significant ( $\mathrm{r}$ $=0.9497 ; \mathrm{P}=0.0057$ ), which explained in $90.2 \%$ the increases observed in grass forage yield, as a function of rest periods. In percentage terms, the participation of LTN represented only 30.9; 33.4; 33.8 and 29.7\% of PTN, respectively for plants at 14 , 28, 42 and 56 days of regrowth, which significantly contributes to the low GDM availability. The low ATN shows that there was no removal of the apical meristems, being grazing or mowing the most recommended practice, so that the predominance of basilar tillers over the axillary ones was not suppress (Costa et al., 2013; Souza, 2018; Silveira, 2020).

The leaf appearance rate (LAR) and leaf area index (LAI) were directly proportional to rest periods, while the leaf elongation rate (LER) was adjust to the quadratic regression model and the maximum value obtained at 50.2 days (Table 2). 
The values of this work, in all rest periods, were lower than those reported by Costa et al. (2008), evaluating A. aureus, under

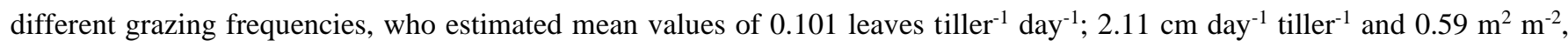
for plants at 45 days of regrowth. Cruz et al. (2021) reported an inverse relationship between appearance and expansion of leaves, as the greater the speed of appearance of leaves, the shorter the period available for their expansion. The LER has a high correlation with GDM grass production and has been use as a criterion for grass selection in genetic improvement works, as it is directly relate to the final leaf length, as smaller leaves are usually associated with higher LAR values (Nabinger \& Carvalho, 2009; Pereira, 2013; Martuscello et al., 2019; Costa et al., 2021).

Table 2. Leaf appearance rate (LAR), leaf expansion rate (LER) and leaf area index (LAI) of Axonopus aureus, as affected by rest periods.

\begin{tabular}{cccccl}
\hline \multirow{2}{*}{ Variables } & \multicolumn{4}{c}{ Rest Periods (days) } & \multirow{2}{*}{ Regression Equation } \\
\cline { 2 - 5 } & 14 & 28 & 42 & 56 & \\
\hline LAR $\left(\right.$ leaf day ${ }^{-1}$ tiller $\left.^{-1}\right)$ & 0.157 & 0.175 & 0.138 & 0.091 & Y $=0.199-0.0017 \mathrm{X}\left(\mathrm{r}^{2}=0.92\right)$ \\
LER $\left(\mathrm{cm} \mathrm{day}^{-1}\right.$ tiller $\left.^{-1}\right)$ & 2.07 & 2.73 & 3.15 & 3.22 & $\mathrm{Y}=1.08+0.0803 \mathrm{X}-0.0008 \mathrm{X}^{2}\left(\mathrm{r}^{2}=0.91\right)$ \\
LAI $\left(\mathrm{m}^{2} / \mathrm{m}^{2}\right)$ & 0.68 & 1.11 & 1.45 & 1.58 & $\mathrm{Y}=0.445+0.0217 \mathrm{X}\left(\mathrm{r}^{2}=0.95\right)$ \\
\hline
\end{tabular}

Source: Research data.

\section{Conclusion}

The green and total dry matter yields, tiller number, axillary tiller number, leaf area index, live tiller and leaf number was positive affected by rest periods. However, the opposite was observe for leaf appearance and elongation rates, while dead dry matter yields were not affected by rest periods.

Considering the low availability of green dry matter from Axonopus aureus, it is recommended to use some pasture management practice, preferably grazing, in order to remove dead material and of low nutritional value to allow a more vigorous regrowth of the grass at the beginning of the rainy season.

\section{References}

Braga, R. M. (1988). A agropecuária em Roraima: considerações históricas, de produção e geração de conhecimento. Boa Vista: Embrapa Roraima. 63p. (Embrapa Roraima. Documentos, 1).

Carrèrre, P., Louault, F., \& Soussana, J.F. (1997). Tissue turnover within grass-clover mixed swards grazed by sheep: methodology for calculating growth, senescence and intake fluxes. Journal of Applied Ecology, 34, p.333-348. https://doi.org/10.2307/2404880

Costa, N. L., Mattos, P. S. R., \& Bendahan, A. B. (2008). Morfogênese de duas gramíneas forrageiras nativas dos lavrados de Roraima. Pubvet, 2, (43), Art\#410.

Costa, N. L. (2014). Formação, manejo e recuperação de pastagens em Rondônia: Embrapa Rondônia. 217p.

Costa, N. L., Moraes, A., Monteiro, A. L. G., Motta, A. C. V., Oliveira, R. A., \& Rodrigues, A. N. A. (2013). Forage productivity and morphogenesis of Axonopus aureus under different nitrogen fertilization rates. Revista Brasileira de Zootecnia, 42, 541-548. https://doi.org/10.1590/S151635982013000800002

Costa, N. L., Jank, L., Magalhães, J. A., Bendahan, A. B., Rodrigues, B. H. N., \& Santos, F. J. S. (2021). Forage productivity and chemical composition of Panicum maximum cv. Mombaça under defoliations intensities and frequencies. Research, Society and Development, 10 , (8), p. e42910817494. https://doi.org/10.33448/rsd-v10i8.17494.

Cruz, N. T., Pires, A. J. V., Fries, D. D., Jardim R. R., \& Sousa B. M. L. (2021). Fatores que afetam as características morfogênicas e estruturais de plantas forrageiras. Research, Society and Development, 10 (7), e5410716180. https://dx.doi.org/10.33448/rsd-v10i7.16180

Gianluppi, D., Gianluppi, V., \& Smiderle, O. (2001). Produção de pastagens no cerrado de Roraima. Boa Vista: Embrapa Roraima, 4p. (Embrapa Roraima. Comunicado Técnico, 14)

Heringer, E., \& Jacques, A. V. A. (2002). Acumulação de forragem e material morto em pastagem nativa sob distintas alternativas de manejo em relação às queimadas. Revista Brasileira de Zootecnia, 31 (3), p.599-604. https://doi.org/10.1590/S1516-35982002000300009 
Research, Society and Development, v. 10, n.9, e56310918536, 2021

(CC BY 4.0) | ISSN 2525-3409 | DOI: http://dx.doi.org/10.33448/rsd-v10i9.18536

Lemaire, G., \& Agnusdei, M. (2000). Leaf tissue turnover and efficiency of herbage utilization. In: Lemaire, G., Hodgson, J. \& Moraes, A. (Eds). Grassland ecophysiology and grazing ecology. London: CAB International. p.265-288.

Lemaire, G., Hodgson, J., \& Chabbi, A. (2011). Grassland productivity and ecosystem services. Cabi, Wallingford. 287p.

Martuscello, J. A., Rios, J. F., Ferreira, M. R., Assis, J. A., Braz, T. G. S., \& Cunha, D. N. F. (2019). Produção e morfogênese de capim BRS Tamani sob diferentes doses de nitrogênio e intensidades de desfolhação. Boletim de Indústria Animal, 76, 1-10. https://doi.org/10.17523/bia.2019.v76.e1441

Mochiutti, S., Meirelles, P. R. L., \& Souza Filho, A. P. (2009). Efeito da frequência e época de roçada sobre a produção e rendimentos das espécies de pastagem nativa de cerrado do Amapá. In: Reunião da Sociedade Brasileira de Zootecnia, 36., 2009, Porto Alegre. Anais. Porto Alegre: SBZ, 3p. (CD-ROM).

Nabinger, C., \& Pontes, L. S. (2002). Manejo da desfolha. Simpósio sobre manejo da pastagem. FEALQ, Jaboticabal. p.133-158.

Nabinger, C., \& Carvalho, P. C. F. (2009). Ecofisiología de sistemas pastoriles: aplicaciones para su sustentabilidad. Agrociencia, 13, 18-27.

Pereira, V. V. (2013). A importância das características morfogênicas sobre o fluxo de tecidos no manejo de pastagens tropicais. Revista em Agronegócios e Meio Ambiente, 6, 289-309.

Pereira, A. S., Shitsuka, D. $\quad$ M., Pereira, F. J., \& $\quad$ Shitsuka, R. (2018). Metodologia da pesquisa científica. [e-book]. Santa Maria. UAB/NTE/UFSM. https://repositorio.ufsm.br/bitstream/handle/1/15824/Lic_Computação Metodologia PesquisaCientifica.pdf?sequence $=1$.

Sarmiento, G., Silva, M. P., Naranjo, M. E., \& Pinillos, M. (2006). Nitrogen and phosphorus as limiting factors for growth and primary production in a flooded savanna in the Venezuelan Llanos. Journal of Tropical Ecology, 22 (3), 203-212. https://doi.org/10.1017/S0266467405003068

Silveira, R. K. (2020). Manejo ecofisiológico das gramíneas Megathyrsus maximus (Panicum maximum) cv. Tanzânia, Mombaça e Massai. Veterinária e Zootecnia, 27 (1), 1-13. https://doi.org/10.35172/rvz.2020.v27.421

Souza, J. A. S. (2018). Produção de gramíneas forrageiras dos gêneros Urochloa e Megathyrsus nas condições edafoclimáticas de Manaus, AM. $58 \mathrm{f}$. Dissertação. (Mestrado em Agronomia Tropical). Universidade Federal do Amazonas.

Tesk, C. R. M., Cavalli, J., Pina, D. S., Pereira, D. H., Pedreira, C. G. S., Jank, L., Sollenberger, L. E., \& Pedreira, B. C. (2020). Herbage responses of Tamani and Quênia guineagrasses to grazing intensity. Agronomy Journal, 201, 1-27. https://doi.org/10.1002/agj2.20189 